\title{
Manifestações barrocas: Jongo e Folia no quilombo de Colônia do Paiol
}

\author{
Carla Ladeira Pimentel Águas \\ Universidade de Coimbra
}

\begin{abstract}
O presente artigo utiliza a metáfora do barroco (Santos 2002) para refletir sobre duas manifestaçóes culturais existentes na região da comunidade afrodescendente de Colônia do Paiol, localizada no Estado de Minas Gerais, Brasil. A partir deste aporte teórico, e utilizando entrevistas semiestruturadas e a observação direta como estratégias metodológicas, as celebrações da Folia de Reis e do Jongo são pensadas desde a perspectiva das suas ambivalências e polissemias, que apontam para as possibilidades de resistência em contextos de silenciamento.

Palavras-chave: barroco, quilombo, jongo, folia de reis, resistência
\end{abstract}

\section{INTRODUÇÃo}

O barroco foi um tempo de mudanças. Ele foi uma reação às inconstâncias da sua épo$\mathrm{ca}$ - quando valores e comportamentos foram postos em causa, alteraram-se as estruturas de classe, cresceram o banditismo, as revoltas, os motins: "É, de facto, uma época de crise, mas é também uma época de transição para novos modos de sociabilidade", afirma Boaventura de Sousa Santos (2002: 332).

Muitos autores encontraram no ethos barroco uma inspiração para se pensar sobre os nossos dias. Características transgressoras, tais como o excesso e a ambiguidade, serviram de mote para a construção de análises acerca da atualidade. Partindo da metáfora do barroco desenvolvida por Santos (2002), o objetivo deste artigo é refletir sobre as celebrações existentes no quilombo de Colônia do Paiol, uma comunidade afrodescendente situada no município de Bias Fortes, Estado de Minas Gerais.

O barroco é uma das três metáforas criadas por Boaventura de Sousa Santos (2002) para descrever as subjetividades emergentes e emancipatórias. O autor afirma que o pensamento crítico, para ser eficaz, tem que assumir uma posição paradigmática, a partir de uma crítica radical 
do paradigma dominante. Segundo ele, vivemos um momento de transição, cujos protagonistas são subjetividades individuais e coletivas capazes de conceber e desejar alternativas sociais emancipatórias. Disposta a enfrentar competições paradigmáticas com as forças hegemônicas, estas subjetividades devem ser guiadas por três grandes topoi: a fronteira, o barroco e o Sul.

A fronteira representa formas de sociabilidade propícias ao diálogo: o termo deve ser entendido como uma forma de sociabilidade e um local privilegiado para o encontro com o outro, onde se desenrolam negociações e traduções interculturais. $\mathrm{O}$ topos do barroco busca retratar uma subjetividade perplexa, dilemática e transgressora - em última análise, uma subjetividade desestabilizadora (Santos 2006). Portanto, o que a metáfora do barroco propõe não é a busca de legitimação de um poder decadente, mas o seu lado subversivo; uma forma excêntrica de modernidade gerada a partir da criatividade marginal. Já a metáfora do Sul busca representar o olhar desde as margens - ou seja, a perspectiva política das periferias do sistema-mundo.

Dentre os inúmeros aspectos que compõem a metáfora do barroco, destaco neste artigo as possibilidades de hibridismo, ambivalência e dissimulação que a caracterizam - a que Bolívar Echeverría (1998) denominou como "opção pelo terceiro excluído". Tais aspectos parecem-me produtivos para se pensar em formas intersticiais de resistência no contexto do Brasil escravista e no contexto quilombola. Estas vontades cifradas (Toro 2009) lançaram mão da ambiguidade dos sentidos para criar saídas para a sobrevivência. A ambivalência era, portanto, uma aliada.

Quanto ao termo "quilombo", surgiu no âmbito da América colonial portuguesa, para denominar comunidades negras compostas por homens e mulheres escravizados e seus descendentes - que conseguiam escapar do sistema escravista ao formarem coletividades paralelas às agruras da estrutura vigente. Portanto, era incluído no vocabulário oficial para designar um território criminalizado, que fora alvo de duras repressões.

Com o fim do sistema escravista, os quilombos mantiveram a sua lógica de existir, enquanto espaços de resistência diante de uma sociedade construída a partir da exclusão (Campos 2005). Porém, a palavra "quilombo" desapareceu da legislação brasileira, para reaparecer cem anos depois da abolição da escravatura, em 1988. A Constituição Federal promulgada naquele ano, através do Artigo 68 do Ato das Disposições Constitucionais Transitórias (ADCT), atribuiu aos habitantes daquelas comunidades o direito sobre as terras que ocupavam.

A partir da promulgação da Constituição Federal, as especificidades étnico-culturais de tais comunidades passaram a chamar a atenção dos investigadores, que concentraram-se na formulação de novos conceitos. Em 1994, o Grupo de Trabalho sobre Terra de Quilombo, realizado pela Associação Brasileira de Antropologia (ABA), produziu um documento no qual definia parâmetros para a atuação sobre o tema. Segundo o texto,

Contemporaneamente, $[\ldots]$ o termo quilombo não se refere a resíduos ou resquícios arqueológicos de ocupação temporal ou de comprovação biológica. Também não se trata de grupos isolados ou de uma população estritamente homogênea. Da mesma forma, nem sempre foram constituídos a partir de movimentos insurrecionais ou rebelados mas, sobretudo, consistem em grupos que desenvolveram práticas cotidianas de resistência na manutenção e reprodução de seus modos de vida característicos e na consolidação de um território próprio (ABA apud O’Dwyer 2002: 18-19).

Para Bandeira e Sodré (1993), o quilombo da atualidade pode ser caracterizado como grupo social de negros compartilhando relações sociais tipificadas a partir do uso coletivo da terra, 
fundado nos princípios do igualitarismo e da reciprocidade, caracterizado por afiliação de cor, laços de parentesco, localidade e práticas culturais. Ilka Boaventura Leite enfoca o quilombo "como conceito sócio-antropológico para discutir suas atuais implicações teóricas e políticas, principalmente no que diz respeito ao quadro atual de exclusão social do Brasil" (Leite 2000: 333).

Pesquisa realizada pelo Centro de Documentação Eloy Ferreira da Silva (Cedefes) ${ }^{1}$ aponta para a existência atual de cerca de 400 quilombos em Minas Gerais, distribuídos por cerca de 150 municípios. Existem 128 processos de titulação das terras em andamento no Instituto Nacional de Colonização e Reforma Agrária (Incra), mas apenas uma área efetivamente titulada, o quilombo Porto Corís.

No caso específico de Colônia do Paiol, comunidade situada no município de Bias Fortes, na Zona da Mata mineira, abriga hoje cerca de 250 famílias e sua origem deve-se à doação de terras feita pelo fazendeiro José Ribeiro Nunes no ano de 1891 a nove de seus ex-escravos. Esta história permaneceu por muito tempo resguardada apenas pela memória coletiva, até que, em 2005, o antropólogo Djalma Antônio da Silva localizou o documento de doação no Arquivo Público do município de Barbacena (MG).

Cada família de Colônia do Paiol possuía uma parcela de terras para plantio. Porém, ao longo do século XX, fazendeiros do entorno foram invadindo o território. De acordo com Djalma Silva (2005), desde o início da doação, as terras eram cultivadas pela comunidade, mas a produção era insuficiente para o sustento do grupo, que multiplicou-se com o tempo. Premida num enclave e cercada por fazendas, a comunidade foi confrontada por crescentes problemas de sustentabilidade.

A perda das terras e a falta de recursos desencadearam um forte êxodo dos habitantes da comunidade para as periferias urbanas, especialmente para a sede de Bias Fortes e para o município de Juiz de Fora, situado a $52 \mathrm{~km}$. Dentre os que ficaram, muitos homens passaram a realizar trabalhos agrícolas sazonais em outras regiões, nas chamadas "turmas", que são contratadas por fazendas de Minas Gerais, Rio de Janeiro e São Paulo.

Mas a migração não implicou necessariamente em desvinculação. Em termos gerais, o êxodo rural, que se acelerou a partir da década de 1970, ${ }^{2}$ representou um incremento econômico para os que saíram e para os parentes que permaneceram na comunidade. Muitos dos que conseguem juntar algum dinheiro, optam por comprar terrenos e voltam para o quilombo.

Quanto à educação, o acesso é difícil. As crianças frequentam o Ensino Fundamental, mas, se quiserem dar prosseguimento aos estudos, precisam deslocar-se para o núcleo urbano de Bias Fortes ou migrar. Duas mulheres de Colônia do Paiol conseguiram ingressar no Ensino Superior, através de um curso particular de Pedagogia na modalidade à distância, disponibilizado na sede do município.

A comunidade, cravada nas montanhas, é constituída hoje por algumas ruas, onde se es-

1 Cf. em www.cedefes.org.br

2 O incremento da imigração a partir deste período deve-se a dois fatores principais: por um lado, a implementação da lei do usucapião, que levou os fazendeiros a deixarem de oferecer as suas terras à meia para o plantio. Além disso, houve uma redução no preço do leite e dos produtos agrícolas. 
palham casas de tijolos ou adobe. Muitas delas não são pintadas, mas cobertas por barro - que confere belas tonalidades às paredes, variando entre o branco, o laranja e o castanho. Os jovens que permanecem no quilombo erguem as casas nos espaços cedidos pelos membros mais velhos da família, para constituírem os próprios núcleos familiares.

A partir da sua recente inclusão no movimento quilombola, Colônia vive hoje um processo de reorganização interna, que passa pela busca de dinamização da associação do quilombo, através de uma nova diretoria, e pela criação da Irmandade de Nossa Senhora do Rosário e São Benedito - que buscará envolver, inclusive, os membros já migrados da comunidade. O processo de regularização das terras foi iniciado em 2004 e, atualmente, o quilombo possui a certidão emitida pela Fundação Cultural Palmares - documento que antecede o Relatório Técnico de Identificação e Delimitação (RTID).

Neste artigo, busco refletir sobre os caminhos de resistência tratados pela metáfora do barroco, a partir de uma abordagem qualitativa e utilizando a observação direta e entrevistas semiestruturadas como estratégias metodológicas. ${ }^{3}$ Começo por realizar uma breve análise sobre o contexto das comunidades quilombolas no Brasil, para a seguir refletir sobre o barroco - especialmente acerca das suas ambivalências e dissimulações. A partir deste aporte teórico, descrevo dois aspectos vivenciados pelo quilombo de Colônia do Paiol: a tradição da Folia de Reis e a dança do Jongo.

\section{O QUILOMBO COMO ESPAÇO DE RESISTÊNCIA}

A primeira definição formal de quilombo surgiu em 1740, através de uma consulta do rei de Portugal ao Conselho Ultramarino: "Toda habitação de negros fugidos que passem de cinco, em parte despovoada, ainda que não tenham ranchos levantados e nem se achem pilões nele" (Almeida 2005: 102). Arruti observa que tal definição, que aparecia tanto na legislação colonial quanto imperial, ${ }^{4}$ assumia uma forma explicitamente indefinida, com o objetivo de abarcar, sob um mesmo instrumento repressivo, o maior número possível de situações:

O uso do termo [quilombo] nunca teve um interesse descritivo, mas, antes de tudo, classificatório, delimitando um objeto que, na realidade, incluía diversas formações sociais muito diferentes entre si. Enfim, o 'quilombo' é uma daquelas categorias classificatórias que respondem à necessidade do Estado de produzir unidades genéricas de classificação para a intervenção e controle social (Arruti 2006: 173).

A partir deste conceito inicial, encontramos alguns elementos que sobrevivem até hoje no

3 A reflexão aqui apresentada deriva da tese "Quilombo em festa: pós-colonialismos e os caminhos da emancipação social”, produzida no âmbito do Programa de Doutorado em Pós-Colonialismos e Cidadania Global do Centro de Estudos Sociais e da Faculdade de Economia da Universidade de Coimbra, desenvolvida com o financiamento da Fundação para a Ciência e a Tecnologia de Portugal. Tratou-se de um estudo comparado entre três comunidades quilombolas de diferentes regiões do Brasil - Colônia do Paiol, em Minas Gerais, Mata Cavalo, em Mato Grosso e Conceição das Crioulas, em Pernambuco. A partir de uma perspectiva teórica pós-colonial, busquei desenvolver uma descrição densa, com o propósito de analisar os vínculos entre festa e resistência no contexto quilombola.

$4 \mathrm{Na}$ legislação imperial, cai de cinco para três o número de fugidos. 
senso comum no que se refere à ideia de quilombo: a palavra vem associada à fuga e ao isolamento. Porém, segundo Alfredo Wagner Berno de Almeida,

Ora, fuga, isolamento, quantidade mínima, podiam bem estar na cabeça de nossos legisladores da Constituição de 1988, que imaginaram um instrumento excepcional, restritivo e também algo isolado. Não imaginaram [os quilombos] dentro das grandes propriedades, mas fora do alcance delas; quer dizer, fora da civilização (Almeida 2005: 231).

Para o autor, muitas vezes a solidez da fronteira étnica se dava na transação comercial, que é justamente o contrário de isolamento. Além disso, vários quilombos foram erguidos nos arredores das cidades e frequentemente mantinham atividades comerciais com outros grupos sociais. A comunicação era, aliás, uma especialidade de muitos deles, ao ponto de serem criadas redes de solidariedade entre os quilombolas e outros segmentos, movidas pelos interesses de cada um dos grupos - servindo, inclusive, como teias de proteção para as comunidades.

Nessas redes, circulavam mercadorias e informações, principalmente. Em muitos casos, as notícias "corriam" entre os diversos agrupamentos, viabilizando estratégias para enfrentar os inimigos (Campos 2005). Além disso, os grupos fugidos articulavam-se com as populações escravizadas das senzalas para viabilizar novas fugas, abastecer o quilombo e obter informações. Havia, inclusive, quilombos interligados como federações, que formavam grupos interdependentes.

Segundo Campos (2005) a palavra "quilombo" era, na verdade, uma designação de fora. No Brasil, os moradores destas comunidades preferiam chamá-las de "cerca" ou "mocambo". Especialmente no Maranhão, são também comuns as designações "terras de preto", "terras de índio" ou "terras de santo".

Além disso, a existência de quilombos nunca foi privilégio do Brasil. Onde houvesse negros escravizados, lá estavam eles. Nas colônias inglesas, estas comunidades foram chamadas de marrons; nas francesas, grand marronage; nas espanholas, palenque e cumbes, dentre outros exemplos.

Tão variadas quanto os nomes eram as suas origens. Os quilombos foram formados a partir de diferentes formas de acesso à terra, sendo que a fuga de escravos é a mais conhecida. Porém, muitos outros motivos poderiam originar uma comunidade: as doações feitas pelos senhores ou pela Igreja; terras recebidas por serviços prestados em períodos de guerra; fazendas abandonadas em função do declínio dos ciclos econômicos e assim por diante.

Os quilombos originados da desagregação de fazendas - a que Almeida (2002a) designa como campesinato pós-plantation - foram relativamente comuns na época do declínio das culturas de açúcar e algodão, dois produtos cujos preços oscilavam muito no mercado externo. Também era possível que um quilombo se originasse de ocupações posteriores à desagregação de ordens religiosas - como no caso dos Jesuítas, expulsos do Brasil pelo Marquês de Pombal em meados do século XVIII - e das desapropriações em regiões de conflito. Segundo Benassar e Marin (2000), algumas províncias que tinham poucos escravos optaram, inclusive, pela libertação antecipada dos cativos para restabelecerem a calma, como foi o caso do Amazonas e do Ceará em 1884. 
A maior destas manifestações foi, sem dúvida, o quilombo dos Palmares. ${ }^{5}$ A discussão sobre esta comunidade reaparece nos movimentos que antecederam ao golpe militar de 1964, para depois reemergir a partir da pressão social pós-ditadura, na fase de redemocratização e no bojo dos movimentos sociais das décadas de 1970 e 80 (Leite 2004). ${ }^{6}$ Portanto, Palmares "entra para a história" graças às pressões políticas dos movimentos sociais - viabilizando um lugar para Zumbi no panteão dos ícones brasileiros e tornando a Serra da Barriga, local onde o quilombo foi instalado, Património Histórico Nacional.

O quilombo dos Palmares foi o exemplo mais visível, mas o fato é que, enquanto houve escravidão, existiram também tais comunidades, que frequentemente geravam medo na classe senhorial e enfrentavam duras repressões militares. O relatório do presidente da Província de Sergipe, escrito em 1876, ilustra este temor por parte das forças dominantes: "São os calhambolas o terror da população do interior. Formando quilombos diferentes, percorrem os engenhos que querem, penetram algumas vezes disfarçados na cidade, roubam, fazem quanta violência entendem" (Arruti 2006: 170).

Apesar da grande diversidade de quilombos, com formas de organização e culturas variadas, de maneira bastante abrangente é possível dizer que muitas das comunidades foram - e continuam a ser - caracterizadas por alguns elementos: destacam-se, por exemplo, as lógicas de reciprocidade entre os seus membros, o uso de áreas comuns e os estreitos vínculos entre terra e identidade.

Estas comunidades foram perseguidas no passado por possuírem um valor polissêmico significavam um precedente perigoso e, ao mesmo tempo, mercadoria a ser recuperada. $\mathrm{Na}$ atualidade, o prisma é outro: tornaram-se um entrave ao agronegócio e um incômodo ao racismo.

Apenas a partir do artigo 68 do Ato das Disposições Constitucionais Transitórias (ADCT) da Constituição Federal de 1988, foram atribuídos direitos territoriais às comunidades remanescentes de quilombos, ao passo que os artigos 214, 215 e 216 acenaram para a necessidade de proteção do patrimônio cultural de tais grupos. E o que era para ser uma simpática homenagem pelos 100 anos da abolição transformou-se em um pesadelo para as elites rurais e em uma brecha para as comunidades negras.

A passagem para o espaço restrito do contrato social, operada pela Constituição de 1988, foi aberta graças, por um lado, às pressões dos movimentos negros e, por outro, ao desconhecimento dos legisladores sobre o próprio país. Desta vez, a invisibilidade dos quilombolas jogou a seu favor.

O contraste entre o quilombo "inventado" e o quilombo real invisibilizado resultou numa óbvia surpresa para o conjunto da sociedade brasileira, que se deparou com a proliferação de co-

5 Palmares situava-se ao sul da então capitania de Pernambuco, região Nordeste do Brasil. Os relatos oficiais sobre este quilombo foram, sem exceção, feitos pelos seus inimigos, e não faltam informações desencontradas. Ainda assim, é possível dizer que o quilombo foi fundado nos últimos anos do século XVI, a partir do triunfo de uma revolta num grande engenho de açúcar (Benassar e Marin 2000).

6 Abdias Nascimento (1980), por exemplo, propôs o termo "quilombismo" para descrever uma proposta pan-africanista para o Brasil. Além disso, iniciou-se uma disputa entre o 13 de maio, data da abolição da escravatura, e o 20 de novembro, dia do herói Zumbi. Arruti (2006) observa que, dentro deste processo de conversão simbólica, surgiram muitas leituras distintas sobre o tema. 
munidades até então “inexistentes”. A aprovação do artigo 68 foi, em parte, garantida pelo imaginário, prevalecente no senso comum, de que os quilombos eram exceções no Brasil. Porém, a base de dados do Governo Federal aponta para a existência de 3.554 quilombos, presentes em todas as regiões, com maior concentração nos estados do Maranhão, Pará, Bahia e Minas Gerais - mas a estimativa é de que existam ainda mais comunidades.

A Constituição de 1988 adicionou mais tempero às discussões sobre os quilombos. Segundo Ilka Boaventura Leite (2004), nos anos seguintes à promulgação constitucional, movimentos negros, núcleos de pesquisa, associações profissionais e sindicais, procuradorias, órgãos dos governos municipais, estaduais e federais passaram a envolver-se, em alguma medida, com o pleito pela titulação das terras dos "remanescentes das comunidades dos quilombos".

O artigo 68 permaneceu sem aplicação até 1995. Mas, durante a comemoração do tricentenário da morte de Zumbi, o tema ganhou novo impulso: o debate sobre os remanescentes de quilombos, até então restrito à Comissão Pastoral da Terra (CPT) e ao Ministério Público Federal (MPF) - focado em um único caso pioneiro, o do quilombo de Rio das Rãs, no sertão baiano - expandiu-se pelo país, tornando-se objeto de debates políticos e análises acadêmicas (Arruti 2006). Além disso, vários estados brasileiros incorporaram o tema às suas próprias constituições.

Acirradas discussões em torno da definição dos critérios de identificação dos grupos quilombolas foram então travadas no plano conceitual - antropológico, histórico e jurídico - e, dentro de tal disputa, o que estava em jogo era "a palavra autorizada, a definição mais acertada e, enfim, a hegemonia sobre um campo em formação" (Arruti 2006: 33). Para Arruti, o dilema concentrou-se na disputa entre o modus normatizador do direito e a ênfase na diversidade da antropologia - portanto, entre a norma e o variante.

A par disso, discussões também foram travadas no campo dos movimentos sociais. A emergência política dos quilombos desencadeou, entre 1986 e 1995, mobilizações de relevância regional e nacional. No Maranhão, a partir de 1986, começaram a ser realizados os Encontros de Comunidades Negras Rurais; no Pará foram organizados os Encontros Raízes Negras e, em 1989, foi fundada a Associação dos Remanescentes de Quilombo de Oriximiná (PA).

No início dos anos 1990, outros estados, como Bahia, São Paulo, Pernambuco e Mato Grosso do Sul, iniciaram suas mobilizações, gerando alguns frutos - como a vitória da área Calunga, em Goiás, que em 1991 foi delimitada como Sítio Histórico e Patrimônio Cultural, e a criação da Reserva Extrativista Quilombo de Frechal em 1992. Em 1994, ocorreu em Brasília o I Seminário Nacional das Comunidades Remanescentes de Quilombo, promovido pela Fundação Cultural Palmares (Ratts 2000). Nesse processo, segundo Arruti (2006), o movimento negro rural apropriou-se da categoria "quilombo", reforçando o debate em torno da questão territorial.

Para se pensar o quilombo a partir do vínculo com a terra, o território deve ser analisado como um fenômeno imaterial e simbólico. "Ele é constituído pelas relações entre os agentes, agências, expectativas, memórias e natureza”, observa Arruti (2006: 323). Todo elemento físico ou histórico que entra na sua composição passa pelo crivo de um processo de simbolização que desmaterializa e, ao mesmo tempo, provoca rearranjos em todo o conjunto. Por isso, para o au- 
tor, a busca de direitos territoriais - necessariamente coletivos - passa pela instituição de uma memória igualmente coletiva e pelo estabelecimento de uma identidade étnica diferenciada.

Esta ideia de territorialidade confronta-se com o mito da igualdade de oportunidades, que aposta no modelo exclusivo da propriedade individual e privada, de terra-mercadoria e sua vinculação à produção mecanizada em larga escala, que visa atender os amplos mercados externos (Leite 2004). Portanto, a relação com o território contraria a ideia de propriedade privada conforme é dada pelo parâmetro capitalista de apropriação do espaço.

Nesse sentido, não há um modelo único: segundo Almeida (2002b), existem constelações de situações de apropriação de recursos naturais (hídricos, florestais e do solo), utilizados segundo uma diversidade de formas e com inúmeras combinações entre uso e propriedade e entre o privado e o comum, perpassadas por fatores étnicos, de parentesco e sucessão, por fatores históricos, por elementos identitários peculiares e por critérios político-organizativos e econômicos. O mesmo autor, ao descrever os diversos tipos de terras tradicionalmente ocupadas, aponta para essa complexidade:

Em termos analíticos, pode-se adiantar, que tais formas de uso comum designam situações nas quais o controle dos recursos básicos não é exercido livre e individualmente por um determinado grupo doméstico de pequenos produtores diretos ou por um de seus membros. Tal controle se dá através de normas específicas, combinando uso comum de recursos e apropriação privada de bens, que são acatadas, de maneira consensual, nos meandros das relações sociais estabelecidas entre vários grupos familiares, que compõem uma unidade social. Tanto podem expressar um acesso estável à terra, como ocorre em áreas de colonização antiga, quando evidenciam formas relativamente transitórias características das regiões de ocupação recente. Tanto podem se voltar prioritariamente para a agricultura, quanto para o extrativismo, a pesca ou para o pastoreio realizados de maneira autônoma, sob forma de cooperação simples e com base no trabalho familiar. As práticas de ajuda mútua, incidindo sobre recursos naturais renováveis, revelam um conhecimento aprofundado e peculiar dos ecossistemas de referência. A atualização destas normas ocorre, assim, em territórios próprios, cujas delimitações são socialmente reconhecidas, inclusive pelos circundantes. A territorialidade funciona como fator de identificação, defesa e força, mesmo em se tratando de apropriações temporárias dos recursos naturais (Almeida 2008: 28-29).

No caso dos quilombos, as modificações do significado da palavra e da própria interpretação do termo "resistência" são tratadas por Leite (2007) através dos conceitos de quilombo trans-histórico, jurídico-formal e pós-utópico. Quanto ao primeiro, refere-se a deslocamentos semânticos - o processo de metaforização - do quilombo, vinculando, através dos tempos, a diáspora africana à conquista do território. O princípio de reconhecimento destas comunidades é a terra que ocuparam e continuam a ocupar, aliada à ideia de tradicionalidade. Passado e presente, tomados como uma continuidade histórica, pressupõem o futuro. Como explica a autora,

O quilombo é um termo usado desde o período colonial escravista. Embora tenha sido também associado a um conjunto de reações que decorrem do prolongamento das relações de dominação em anos recentes, aparece relacionado às mais diversas formas de protesto, conspiração, revolta, fuga e rebelião. Esta constatação nos permite inicialmente afirmar que o quilombo é um conceito trans-histórico, pois atravessa diversos períodos, contextos e situações, trazendo em seu núcleo central, um sentido que se mantém - o da não aceitação das diferentes formas de dominação (Leite 2007: 4).

Em 1988, houve a passagem do quilombo trans-histórico para o quilombo jurídico-formal, ou seja: ele deixou de ser oposição para tornar-se política de Estado. Como decorrência, "um conjunto de situações, antes invisíveis desde a ordem jurídica vigente, emergiu para confrontá-la, para desafiar o princípio universal anteriormente vigente" (Leite 2007: 10). O reconhecimento oficial gera novíssimos sentidos à palavra "resistência", na medida em que uma suposta 
transição pacífica, segura e controlada deveria inverter a ideia de resistência como conflito para a resistência enquanto ordem, através do pacto social.

Mas a fluidez dos processos identitários pode criar fenômenos surpreendentes, mesmo quando a matéria-prima é tão estanque quanto uma categorização legal. Portanto, o "ressurgimento" das comunidades quilombolas vem acompanhado por interessantes fenômenos. Quando a palavra "quilombo" foi incluída na Constituição Federal, seus membros passaram a enquadrar-se dentro de uma concepção que não fazia parte do vocabulário das comunidades antes de 1988.

Como descreve Ilka Boaventura Leite, desde a promulgação da Constituição, ações civis, mobilizações e a criação de associações permitiram às comunidades negras rurais e aos redutos negros das periferias urbanas recompor e reescrever suas narrativas: "O quilombo passa a metaforizar as experiências dos afrodescendentes, mas principalmente as vitórias ocorridas sob o manto anódino do racismo" (2004: 23).

O que se vê hoje no Brasil é uma tentativa das elites de inviabilizar o cumprimento da Carta Magna. Os quilombos vêm se mobilizando em busca da aplicação da lei, mas as elites também se organizam para impedir a "travessia". Como afirma Leite (2007), surgem no Brasil novas formas de dominação que, por sua vez, implicam a emergência de novas formas de resistência - a que a autora denomina quilombo pós-utópico.

A lentidão dos processos de titulação, os entraves da cultura cartorial, a criminalização das lutas camponesas, as prisões injustificadas, as provas forjadas, a falta de acesso ao ensino formal - estes e outros aspectos formatam um "estado de justiça" que, mais uma vez, busca fechar as portas para esta "humanidade banida, empurrada para fora da ordem e tornada fora da lei" (Leite 2007: 17). Nesse sentido, a utopia é substituída por um estado de incerteza em relação a esta nova ordem.

\section{BARROCO, A PÉROLA IMPERFEITA ${ }^{7}$}

A cronologia do barroco não é consensual entre os historiadores. Sem chegar a um veredicto, é possível, porém, optar por traçar suas margens no período que vai desde a etapa final de Michelangelo - que muitos consideram "o pai do barroco" - até o fim do século XVIII, ao estender sua existência para a América Latina (Lisboa 2003; Méndez 2006).

Portanto, o século XVII, enquanto período de transição, revela-se sob diferentes dimensões: é curto no Norte da Europa e longo e decisivo no Sul, bem como nas colônias ibéricas (Echeverría 1998). Em todos os casos, uma caracterização detalhada do barroco exige sempre uma análise localizada, uma vez que se manifestou de diferentes formas, em diferentes regiões.

Porém, é viável arriscar uma caracterização mais ampla, mesmo que sujeita aos desencaixes de sua aplicação nos diferentes contextos. $\mathrm{O}$ gosto barroco, em poucas linhas, pode ser descrito

7 Billi (2005) explica que o termo deriva de Broaki, província da Índia onde os portugueses chegaram em 1510, passando a chamá-la Baróquia. Lá se colhia em abundância um tipo especial de pérolas que apresentavam uma superfície áspera e irregular, cuja coloração mesclava o branco com tons escuros. 
através dos contrastes de ritmos e volumes, vazios e oblíquos, das dimensões excessivas e da acumulação de ornamentos (Cabanne 2001).

A mentalidade barroca pulverizou-se sobre as mais variadas manifestações artísticas: na literatura eclodiram os jogos poéticos, as metáforas e a prevalência conotativa (Ávila 1971); no teatro, predominaram as alegorias; na música, os ecos e diálogos de vozes e instrumentos; na pintura, o trompe l'oeil, o tenebrismo, o tremendismo; o congelamento do movimento gestual na escultura; a retenção da espacialidade cerimonial na arquitetura (Echeverría 1996). Em todos os casos, segundo José Maravall (2009), o barroco buscou produzir certo grau de indeterminação acerca de onde acaba o real e começa o ilusório.

Além disso, foi uma arte conectada à Contra-Reforma, sem, no entanto, resumir-se às suas intenções. Religião versus arte - o paralelismo entre estas duas tendências complementares e contrapostas caracteriza a relação entre barroquismo e contrarreformismo. "Um empate que, como toda obra radicalmente barroca, inclina-se mais para o lado da arte", afirma Echeverría (1996: 186). ${ }^{8}$ Aliás, eu diria, salta para além desta dicotomia.

A religiosidade barroca não ergueu limites rígidos entre o sagrado e o profano. Os jesuítas, imersos no projeto colonial, não negavam o mundo e suas sensações - pelo contrário; o corpo passou a ser visto como uma ferramenta para atingir o espírito. A Contra-Reforma acabou por aproximar-se do sentido religioso popular, ao valorizar as imagens e outros objetos de devoção, que poderiam ser tocados, vistos, sentidos. As relações com o plano da transcendência se organizam e desenvolvem recorrendo a meios, conhecimentos e recursos que são próprios do mundo da experiência (Maravall 2009).

"A mente barroca, acima de guerras e mortes, de enganos e crueldades, de miséria e dor, afirmará uma última concordância dos mais opostos elementos”, descreve Maravall (2009: 259). Por isso, segundo o autor, no fim das contas todo comportamento barroco é uma moral de acomodação. $\mathrm{O}$ desespero perante o esgotamento do cânone greco-latino constituiu uma fonte de sentido objetivo, que levou o barroco ao jogo de paradoxos, enfrentamentos e conciliações entre contrários.

Com a emergência do Iluminismo, o barroco passou a ser visto sob uma perspectiva condenatória e, sobretudo, a partir de uma imagem uniforme e sem fissuras. ${ }^{9}$ Século de ferro, mundus furiosus, tempo de misérias e crimes, tumultos e agitações, ostentações e vergonhas - enfim, época de conflitos historicamente improdutivos - esta foi, segundo Bolívar Echeverría (1998), a caracterização do período. No entanto, o autor alerta que a ideia de caos simples, unitário e absurdo nubla a possibilidade de outra visão, em que emerge um barroco complexo, variado e coerente em seu conflito - uma perspectiva que desafia as novas análises críticas sobre o século XVII.

Mas o degredo não foi perpétuo. Depois de ter sido visto com desconfiança em boa parte do século XIX, o barroco despertou um novo interesse. Em 1855, Jacob Burckhardt publicou

8 Esta e outras traduções para a língua portuguesa são de minha autoria.

9 Inclusive no Brasil, onde a reação academizante predominou no período imperial; um marco nesta direção foi a chegada ao país, em 1816, da Missão Artística Francesa, tendo em mãos a tarefa de introduzir o sistema superior acadêmico e fortalecer o Neoclassicismo. Segundo Ávila (1971), apenas o modernismo retomaria os estudos sobre a arte setecentista mineira. 
sua "Introdução ao Renascimento", desenvolvendo uma análise artística do barroco italiano ainda que sem deixar de apresentá-lo como uma etapa de degradação dos paradigmas clássicos (Bernal 2004).

Em 1888, um de seus discípulos, Heinrich Wölfflin, sistematizou o uso do termo e o introduziu na história da arte. Ele caracterizou o barroco como um estilo oposto ao Renascimento, ao elencar os seus cinco esquemas constitutivos: o predomínio do dinâmico - a cor - sobre o estático, o desenho; a invasão do profundo sobre o primeiro plano; a presença do não representado no representado; a refuncionalização das partes pelo todo da representação; a ação do indistinto, nublando a nitidez do diferenciado. Segundo ele, o interessante do processo residia na passagem de uma arte rigorosa para uma arte livre e pitoresca; de uma forma estrita a uma ausência de forma (Wölfflin 1991). Na leitura de Echeverría (1996), todas essas características falam da insegurança, da confusão e ambiguidade; de uma intenção de converter a percepção da obra de arte num espaço de inquietudes.

Diversos autores abordam o barroco a partir do seu caráter persuasório e vinculado à manutenção dos poderes hegemônicos num mundo em crise, através da infiltração de conteúdos doutrinários. Para Maravall (2009), por exemplo, toda a arte barroca vem a ser um drama estamental - a gesticulante submissão do indivíduo à moldura da ordem social. $\mathrm{O}$ autor fala desde a Europa - mais especificamente, desde a Espanha - e, dentro deste espaço geográfico, desde a perspectiva das elites, na sua luta pela imobilização das irremediáveis transformações em curso.

Os esforços das elites, no entanto, não diluíram os conflitos daqueles tempos de transição. Se, por um lado, o autor define o barroco como uma cultura massiva do Estado absolutista, por outro, sinaliza a existência de rebeldias que contradizem o caráter determinista da persuasão barroca. Caracteriza o europeu do século XVII como um “indivíduo em luta” (Maravall 2009: 260), que trava duras batalhas consigo mesmo e com o entorno. Movimentos de oposição política, rebeldias e conspirações fazem parte do cenário, o que acaba por relativizar a ideia de inescapável submissão das grandes massas populares, frente às exuberantes estratégias das elites.

Mas, se a arte é usada como instrumento para aturdir os sentidos das "almas simples”, essas mesmas "almas" podem abrir espaços de ruptura com os centros de poder a partir da experiência estética e ritual que proliferou - e, a partir de outros moldes, prolifera - nas periferias. Sob este prisma, o barroco não percorreria um só caminho, mas estaria diante de uma bifurcação, gerada a partir da própria complexidade dos meios sociais. Boaventura de Sousa Santos (1994) traça esta diferença entre "dois barrocos": caracteriza, por um lado, um barroco hierárquico, aristocrático, menos excêntrico que cêntrico. Por outro lado, também detecta a existência de um barroco transgressivo, profano (ou mesmo sacrílego), anárquico, heterogêneo, mestiçado, onírico, popular, cujo centro é enfraquecido.

A América Latina foi um território fértil para a proliferação de tais manifestações transgressoras do barroco. Segundo Echeverría (2007), a identidade barroca latino-americana, que boa parte da população do continente assumiu no decorrer de consideráveis períodos da sua história - deixando marcas não apenas na arte e literatura, mas também nos usos linguísticos, políticos e nas formas de vida cotidiana - tem suas origens ainda no século XVI, principalmente no México e Peru, generalizando-se nos séculos XVII e XVIII por outras partes da América. 
$\mathrm{Na}$ sua gênese, está uma forma de comportamento dos indígenas que sobreviveram nas novas cidades, depois que seus pais foram vencidos:

O século XVII na América não pôde fazer outra coisa, na sua crise de sobrevivência civilizatória, que reinventar-se e reinventar também, dentro desta primeira reinvenção, o pré-hispânico. Não pôde fazer outra coisa que colocar em prática o programa barroco (Echeverría 1998: 96).

Os descendentes dos impérios pré-colombianos derrotados, primeiros inventores do barroco latino-americano, estavam - literalmente - entre a cruz e a espada. Como observa Echeverría (1998), submeter-se, colaborar com o mundo e o poder estabelecidos, equivalia a assegurar a marcha da nova economia e a participar em seus benefícios. Mas isso implicava numa morte moral, a renúncia a si mesmo. Por outro lado, rebelar-se ou refugiar-se num lugar inóspito representava o resgate da autonomia e da dignidade moral, mas também poderia significar a morte física.

Diante desta oposição entre assimilação e suicídio, a estratégia utilizada - principalmente pelas camadas mais pobres - foi uma forma peculiar de comportamento, que "consistia em não submeter-se e nem tampouco rebelar-se, ou, inversamente, em submeter-se e rebelar-se ao mesmo tempo" (Echeverría 1998: 181). Esta estratégia latino-americana, a que Echeverría chama de "opção pelo terceiro excluído", significou um salto a um terreno histórico diferente, onde a dicotomia perdia a sua razão de ser e a partir de onde se vislumbrava uma possibilidade de futuro:

A resistência, a reivindicação da 'identidade' americana, era cumprida de maneira tão radical, que obrigava a pôr à prova, na prática, o núcleo da sua proposta civilizatória, a refundar-se e reconfigurar-se para responder às novas condições históricas (Echeverría 1998: 181).

Eleger a "terceira possibilidade”, aquela que não cabe no mundo estabelecido, leva a "viver outro mundo dentro deste mundo" - ou, visto ao revés, "colocar o mundo, tal como existe de fato, 'entre parênteses"” (Echeverría 1998: 176). Trata-se de um parêntesis de encenação; de uma desrealização da contradição e da ambivalência que, sem pretender resolvê-las, lhes confere o status de alegoria.

Echeverría (1996), dentre outros autores, trabalha com o conceito de ethos barroco para caracterizar um princípio de organização da vida social que não se comprometeu com o projeto civilizatório da modernidade capitalista, mantendo-se à margem do seu produtivismo febril. A arte barroca seria apenas um dos modos com que esse ethos se fez presente, através de uma desmesurada estetização da vida cotidiana (Echeverría 1994; 1996).

O que encanta o autor não é propriamente a distância mantida pelo barroco frente ao projeto capitalista; é a forma tomada por este distanciamento. A intrigante convivência entre tradicionalismo e busca de novidades, entre conservadorismo e rebelião, entre amor à verdade e culto à dissimulação, que caracterizam o barroco, fazem com que as suas diferentes tendências se enfrentem, ao mesmo tempo em que as totalidades são protegidas, de forma que as forças centrífugas que ameaçam destruir-se mutuamente possam ser reconciliadas. Mergulhar no "mistério desta contradição estrutural interna" (Echeverría 1998: 123) é, para o autor, o aspecto mais fascinante do estudo do barroco; este seria o ponto central de uma visão inovadora do período, capaz de lançar novos olhares sobre a nossa própria contemporaneidade.

Características como estas têm levado a estudos sobre o barroco, movidos não apenas por 
um interesse histórico e artístico, mas também pela necessidade de compreensão de fenômenos que atingem o nosso próprio tempo. Para Echeverría,

Nada parece casar mais fortemente o nosso curto século XX (1914-1989) com o longo século XVII que a presença em ambos de um fenômeno histórico extremamente particular: a atualidade de um processo de transição perfeitamente maduro, se diria até sobremadurado, que se mantém, no entanto, preso, aturdido, fechado em um círculo do qual não encontra maneira de sair (Echeverría 1998: 126).

Os pontos em comum entre o barroco e a nossa contemporaneidade não passaram despercebidos para Boaventura de Sousa Santos (2002), que o integrou à tríade de metáforas a partir das quais busca caracterizar as subjetividades na transição paradigmática. Como já vimos, ao lado da fronteira e do Sul, a metáfora do barroco emerge como um instrumento de análise da atualidade, cujos elementos dissonantes dão pistas de outras formas de ser e estar no mundo que vão além da ortodoxia do desenvolvimento capitalista da modernidade. Por tratar-se de uma metáfora, a intenção não é designar um estilo, nem identificar uma época ou um ethos cultural:

Utilizo o barroco enquanto metáfora cultural para designar uma forma de subjectividade e de sociabilidade, o tipo de subjectividade e sociabilidade capaz de explorar e de querer explorar as potencialidades emancipatórias da transição paradigmática (Santos 2002: 330).

O que a metáfora do barroco busca expor, desta forma, não é a busca de legitimação de um poder decadente, mas o seu lado de subversão. Segundo o autor, "o ethos barroco constitui os alicerces de um tipo de sociabilidade interessada em se confrontar com as formas hegemónicas de globalização e capaz de o fazer, abrindo assim um espaço para possibilidades contra-hegemónicas" (Santos 2006: 198).

O contexto de crise que deu origem ao barroco, que guarda semelhanças com o nosso próprio tempo, é o que lhe parece ser mais inspirador: "Interesso-me por esta forma de barroco porque, enquanto manifestação de um exemplo extremo de fraqueza do centro, constitui um campo privilegiado para o desenvolvimento de uma imaginação centrífuga, subversiva e blasfema” (Santos 2002: 331).

A debilidade do poder central conferiu ao barroco um caráter aberto e inacabado, capaz de favorecer a autonomia e a criatividade das margens - e o próprio centro pôde reproduzir-se como margem. Gerou-se uma subjetividade perplexa, dilemática. Neste sentido, a sociabilidade barroca é emotiva e apaixonada; busca o gosto, o prazer. Vincula-se ao corpo, ao aqui e ao agora, à ludicidade e, afinal, à utopia. A ideia de catarse - analisada por Fanon (1975) como uma porta de saída para as energias acumuladas, imprescindível para todas as coletividades - está evidentemente presente, mas não só. O que Santos propõe, com esta metáfora, é a construção de um novo senso comum estético e, acima de tudo, reencantado.

O desencanto do senso comum sublinhado por Weber (1982) é, na verdade, um desencanto circunscrito à modernidade capitalista, que está longe de ser universal. O mundo está cheio de sociabilidades e subjetividades encantadas, porém invisibilizadas pelo pensamento ocidental. Este desperdício de experiências faz com que o mundo pareça menor e menos diverso do que na verdade é (Santos, 2006).

Já vimos que, através da opção pelo terceiro excluído, a população da recém-conquistada América Latina deslocou sua insuportável contradição interna para o interior de uma outra lógica - permitindo viver outro mundo dentro deste mundo. Manobras de ressignificação, de 
ocultamento e dissimulação impedem que o modelo hegemônico se instale, com pleno conforto, junto aos grupos sociais subalternizados. Desta forma, a dominação é condenada a ser um trabalho inacabado, mesmo nos espaços em que a resistência aberta tornou-se impossível.

Assim, Boris Toro (2009) define a dissimulação - e a simulação - como técnicas da aparência ou arte do encobrimento. No contexto mediterrânico do século XVII, significou uma resistência racional e criativa à opressão de um poder que começava a infiltrar-se nas consciências, preenchendo o vazio deixado pelos cismas teológicos. Referindo-se a Remo Bodei, descreve:

A dissimulação é, então, segundo o comentador italiano, uma estratégia de sobrevivência e seu uso uma necessidade perante uma forma de poder penetrante e totalitária [...]. A simulação e a dissimulação convertem-se em parte de uma nova forma de prudência, a qual não se define tanto pela administração dos prazeres ou pela aquisição da média justa, mas sim pela cautela (Toro 2009: 173).

Desde uma visão pautada na cultura nagô, Muniz Sodré afirma que "o que o indivíduo humano tem conhecido de permanente é mesmo a ambivalência” (Sodré 2005: 72). Esta, no Ocidente, assume socialmente a feição de instabilidade das forças que se equilibram provisoriamente numa unidade, do jogo contínuo das tensões, das lutas e das seduções - tudo isso acionado pelo movimento simbólico. Para o autor, é esse movimento que impõe limites a todo poder, uma vez que o impede de controlar o vazio que necessariamente o delimita.

A lógica do modelo hegemônico ocidental não se adapta bem às ambivalências. A sua ansiosa busca pela verdade - necessariamente universal - exige uma clara divisão entre os dois lados de uma dicotomia. Céu ou inferno; bárbaro ou civilizado; não há condescendência com os meios-termos, justamente porque a mentalidade cartesiana não vive nas fronteiras. Assim, é inevitável o desconforto quando, no barroco, "a representação do sagrado desliza subrepticiamente para a representação do sacrílego" (Santos 2002: 335).

\section{Folia de Reis: A Celebração de Um nAscimento improvÁvel}

Diz a tradição oral de Colônia do Paiol que a Folia de Reis saía em variadas épocas do ano. Volta e meia, os senhores e capitães-do-mato viam aquele alegre grupo, representando os três reis magos, com seus enfeites, instrumentos e canções, a circularem pela região, pedindo doações de casa em casa. Mal sabiam eles que aquela era também uma estratégia de sobrevivência: se a Folia foi criada para homenagear o difícil nascimento de Jesus, ocorrido numa manjedoura durante a fuga de Maria e José, ali ela era realizada para viabilizar o também difícil nascimento de novas crianças negras, cujas mães fugiam para as matas.

Temendo sofrer represálias, essas mulheres optavam por disfarçar a gravidez e escondiam-se durante o parto. E, nos cortejos das inofensivas Folias, estavam estrategicamente os mais velhos da comunidade, inclusive as parteiras, que iriam ajudar a trazer mais uma criança à vida. Mas não há ninguém melhor do que o senhor Paulo Marinho, ${ }^{10}$ membro mais velho do quilombo, para explicar esta história:

$\mathrm{Na}$ senzala tinha aquelas dona, elas ganhava os neném. Elas ganhava os neném e pra elas não ser chicotada, o quê que elas fazia? Os marido delas punha elas pra ganhar as criancinha no meio do mato. Chegava lá,

10 Ancião, funcionário do município de Bias Fortes. 
pegava esses capim mumbeca, punha lá, fazia cama de capim mumbeca pra elas ganhar os filho lá. [...] As músicas da Folia de Reis, como era os três reis magos, ia três dos mais velhos lá, aquelas dona mais velha ia junto, chegava lá, fazia o parto da dona e ali depois que a dona ganhasse a criança, que arrumasse tudo, é que vinha pra senzala.

Eles iam cantando; e será que era pro dono da fazenda não saber que ia nascer a criança?

Não saber que ia nascer a criança. Aí eles pegou e falou assim: 'A Virgem Maria ganhou a criança dela numa manjedoura, o menino Jesus numa manjedoura, no meio do mato. Assim vocês também vai ganhar as crianças no meio do mato como a Virgem Maria. E vocês vai ficar ciente que vocês não vai ser escorraçada durante o parto de vocês. Elas ficava segura. Depois que elas ganhava, que tava tudo tranquilo, que eles pegava e levava pra senzala. O capitão chegava e falava assim: 'Da onde saiu esse negro? $\mathrm{Da}$ onde saiu esse negro? Como esse negro nasceu?' Eles pegava e falava assim: 'O negro nasceu como a Virgem Maria ganhou o menino Jesus'. E aí o quê é que ainda fazia? Nisso, ainda, eles apanhava. Eles não queria que eles fizesse aquilo. A vontade deles era que as criança não vingasse. Mas como já tinha ido lá, já tinha ganhado, eles não podia fazer nada. Eles falava que agora não tinha o que fazer. É onde surgiu a Folia de Reis, que é os três reis magos, compreende?

A “sobreposição de Marias” - da Maria mãe de Jesus às "Marias” escravizadas, sujeitas ao mesmo destino de fuga contra "os demônios", como sugeriu Paulo Marinho - revela estratégias de dissimulação, usadas para driblar a extrema violência do regime escravista. Para relembrar Echeverría (1998), tais estratégias pressupõem concessões num plano mais evidente, a fim de que vitórias sejam viáveis num plano mais profundo, dentro de um ambiente repressor. Trata-se de uma oposição possível.

A memória das origens da Folia de Reis de Colônia do Paiol associa-se, portanto, ao conceito de dissimulação: à primeira vista, o folguedo remete à conversão dos negros escravizados ao cristianismo - o que representa, por um lado, certa aceitação ou absorção do modelo religioso imposto pelos colonizadores. A partir de um olhar mais profundo, que atinge outros planos, a mesma Folia pode também significar uma intrincada estratégia de sobrevivência e de viabilização da descendência, num contexto de violência absoluta.

Um terceiro olhar sobre a Folia de Reis pode ainda levar à sua ambivalência: a triangulação estabelecida entre o folguedo, o menino Jesus e a criança negra recém-nascida, que foi mantida através dos tempos pelos mecanismos da memória, não precisa optar por um extremo ou outro. O senhor Paulo Marinho, por exemplo, fala da devoção a Jesus e dos horrores da escravidão com o mesmo empenho - sendo que, obviamente, o segundo tema causa-lhe perplexidade - sem ter que optar por um ou outro significado.

Encontramo-nos assim numa encruzilhada semântica: não me parece insensato argumentar que a Folia é uma coisa e outra ao mesmo tempo. Os foliões saem às ruas, pedindo suas esmolas de casa em casa, para homenagear a chegada do Salvador. Porém - e simultaneamente tem-se ainda hoje a ritualização de uma memória de sofrimento e da possibilidade de superação através de mecanismos ocultos. Ao perseguirem "a estrela do Oriente que apareceu lá no céu", os cantadores anunciam o nascimento de Jesus, da mesma forma com que também celebram o nascimento de uma criança negra, que veio ao mundo, apesar de tudo. Através da opção pelo terceiro excluído, os dois milagres são louvados ao mesmo tempo. 


\section{JONGO: CURA OU CULTURA?}

Quando perguntei ao senhor Paulo Renê Pereira ${ }^{11}$ em que consistia o Jongo, recebi uma resposta inusitada. Eu esperava uma descrição das características, etapas e personagens do folguedo, mas a sua explicação girou em torno dos seus efeitos:

Com essa dança, ela traz um fluido bom que termina o sofrimento. De repente chega uma pessoa aqui no meio da gente, cheio de problema, começa a cantar, a cabeça dela muda, é outra. Isso que é o Jongo: é uma força extraordinária que nós não sabe de onde vem.

Apontando para o seu grupo, que ensaiava em frente à Matriz de Bias Fortes, enquanto esperava pelo transporte que os levaria a uma apresentação cultural numa cidade vizinha em Minas Gerais, ele acrescenta: "Essas pessoas, mesmo nós cantando na roda, aqui assim, nós identifica mais ou menos o que tá acontecendo. Na hora. Ali nós ajuda a pessoa, canta pra aquela pessoa, põe aquela pessoa alegre. Uns começa a chorar. O Jongo é isso”.

Ou seja: mais do que fornecer uma descrição, o que importava para ele era explicar o Jongo como um espaço dentro do qual uma pessoa poderia ser ajudada, ou mesmo curada, caso sofresse de algum mal. Portanto, Renê Pereira, coordenador do grupo de Bias Fortes, respondia como quem não apenas "vê", mas "vive" o Jongo.

O desencontro entre pergunta e resposta mostra que eu e o entrevistado partíamos de ângulos completamente diferentes. É claro que a conversa sairia desconexa: eu falava desde uma perspectiva acadêmica, enquanto ele falava desde a perspectiva de quem vive "outro mundo dentro deste mundo" - portanto, segundo o meu argumento, desde uma perspectiva metaforicamente barroca.

Diante do "susto" provocado pela resposta do senhor Renê - o abalo causado pelo encontro entre "mundos" - não cedi à tentação: não insisti em puxar o entrevistado para o meu lado da conversa, forçando-o a esclarecer quantos são os participantes do grupo, quais os significados dos símbolos ali presentes, de que tratam as letras das canções etc. Preferi entregar-me à sua condução sobre o assunto.

Só mais tarde dei-me conta da generosidade daquela resposta. Quando o coordenador do grupo selecionou, dentre o vasto leque de informações de que dispõe sobre o folguedo, aquela que melhor me daria a conhecer o Jongo - digamos, o seu ponto central e definitivo - revelou que o cerne está justamente na sua ambivalência.

O Jongo é uma manifestação ancestral do samba e do pagode, existente no Sudeste do Brasil, tendo suas origens relacionadas à cultura do café e da cana-de-açúcar. No Brasil escravista, serviu como uma estratégia de comunicação em ambientes de extremo silenciamento, em que se revelavam processos de metaforização que passavam despercebidos aos ouvidos dos atentos intendentes. Paulo Dias, por exemplo, cita o depoimento de Dona Zé, de Guaratinguetá (SP), que explica as mensagens sutis embutidas na cantoria:

Os escravo num podia comunicá com ninguém, eles num tinha liberdade, né? Então, quando eles entrava na senzala é que eles ia participá um co outro. Então, no meio eles faziam a roda de Jongo e, ali, cada um cantava o Jongo falando o que queria falá, mas sobre... pela canção. Daí, um entendia o que tinha que sê feito.

11 Adulto, morador do município de Bias Fortes. 
Às vezes o que se passô no dia, o que ia acontecê. Então, um já avisava o outro. E, era por meio de ponto de Jongo que era comunicado as coisa (Dias 2001: 875).

Para que seja desenvolvida a análise do Jongo de Renê Pereira, voltemos ao barroco. Já foi discutido que ele traz uma contradição interna, deslocada para outra lógica através da opção pelo terceiro excluído. Esta ambiguidade é propícia à quebra de dicotomias - entre aparência/ realidade, sagrado/profano, riso/seriedade.

No Jongo cantado em Bias Fortes, é possível detectar novas bifurcações de sentidos: por um lado, é um alegre folguedo, que segue ao ritmo da sanfona, pandeiro e violão. Por outro, é um momento em que os iniciados são capazes de ver como está cada um dos membros do grupo, aliviando as dores de quem precisa. É como se, naquele contexto ritual, os corpos ficassem "transparentes", deixando notar as necessidades das almas - isso, se o uso desta oposição corpo/ alma fosse cabível. Renê Pereira explica: "[O jongo] mostra pra gente, que canta, energia negativa; 'vamo ajudar essa pessoa, que ela precisa".

Visto o cenário, dá-se a ação: o grupo mobiliza-se para intervir junto àqueles que, dentre os participantes, estiverem necessitados. Quando todos cantam para aquele que precisa, este sente o bem-querer coletivo e é curado. "A pessoa cresce", descreve o coordenador. Renê Pereira ilustra com o caso de um idoso das redondezas, que andava desiludido com a vida:

Eu já vi um senhor de idade - um senhor daqui de Bias Fortes, morava lá [aponta para uma direção da cidade] - ele ficava só dentro de casa, na beira do fogão. 'Vamo com nós, vamo jongá!' 'Não, isso aí é bobeira'. 'Vamo com nós, vamo lá, o senhor vai ver como o senhor vai sentir bem'. Aí ele foi. Aí chegou lá, ele não ficou cantando não. Ele ficou quietinho num cantinho, depois ele começou dançar. Aí ele foi e falou assim: 'Ah, porque esse negócio é bão!' Voltou no outro dia, aí nós fez uma dança. A gente já cantou o Jongo, dança um forrozinho. Ele dançou, o hômi mudou, ficou novo, durou muitos anos, resolveu até casar. O Jongo é isso; o Jongo resgata.

Um olhar estranho não capta tais dinâmicas internas. Então, qual a verdade do Jongo? É cultura ou é cura? O interessante deste e de outros folguedos é que se torna impossível extrair uma única verdade. Tudo depende da perspectiva a partir da qual são vistos, tal como acontece no labirinto de espelhos que caracteriza o barroco. O Jongo é um, é outro, e são ambos ao mesmo tempo.

Colônia do Paiol já teve, há tempos, o seu Jongo. Com raízes que penetravam na época da escravidão, o grupo formava-se nas idas e vindas do trabalho. Como explica o senhor Paulo Marinho, "nós ia capinar, aí saía um mutirão igual". Durante os trajetos, geralmente longos, a realidade cotidiana era mergulhada no mistério - dando indicações dos profundos elos que unem a labuta diária ao sagrado.

Ao cantar e dançar o Jongo, o grupo de trabalhadores sacralizava o trajeto. A rotina dava lugar ao maravilhoso. Os quilombolas de Colônia do Paiol falam com entusiasmo desta magia, e de como ela era frequentemente colocada à prova: abundam casos daqueles membros da comunidade que, empenhados em avaliar os jongueiros, escondiam objetos pelo caminho. Sabonetes, bebidas, queijos - qualquer peça, intencionalmente ocultada, servia para testar o poder ali presente. Era esperado que os líderes do grupo pressentissem a existência do que fora posto no caminho, adivinhando o seu esconderijo. É como descreve o senhor Paulo Marinho:

O que é que eles fazia? Comprava uma meia garrafa de pinga, pegava e punha lá por baixo da ponte. Enfiada 
no barranco, por baixo da ponte. Padrinho Geraldinho pegou um queijo, pôs dentro da sacola plástica e pôs lá. Eles [os líderes do Jongo] chegou perto da ponte, eles começava a arrancar grama com as mão assim, com os dente assim, com os dente lá, pastava a grama com o dente, ia rodando, rodando, dum lado e do outro; quando caíram n'água. Eles caíram n’água todos os dois. Nós falou: ‘O que é que é isso aí?’ Eles falou: 'Aqui tem dendê! Aqui tem dendê!' Eles juntou lá debaixo da ponte, enfiou a mão debaixo e o compadre Negrinho saiu com aquela garrafa na boca, assim.

O desafio serve, assim, para averiguar se o jongueiro realmente tem o dom. Nesse caso, ele pressente o objeto - como se fosse uma barreira - e "cavuca, cavuca, qui nem um tatu. Enquanto não acha, não passa”, explica Paulo Marinho.

Para viver o Jongo, é preciso ser iniciado. O interessante é que a sua função ritual não está explícita, como acontece quando, por exemplo, se visita um terreiro de Candomblé. Para o olhar desatento, ali está uma apresentação cultural, uma tradição; apenas um grupo de pessoas a tocar, cantar e dançar. O religioso está dissimulado.

Mais que isso: o Jongo é curativo e sagrado, mas, ao mesmo tempo, "anima qualquer festa", como salienta Renê Pereira. Aqui está corporificada, a meu ver, a dimensão do terceiro excluído; o salto para além da ambivalência, que torna impossível se tomar partido por um único sentido. Dali emerge a quebra de dicotomias entre o riso e a seriedade, entre o sagrado e o profano, entre aparência e realidade. Algumas pistas revelam a sobreposição de significados sobre o mesmo significante, ou da presença do outro mundo dentro deste mundo:

A arte barroca propriamente dita, em contraposição com a arte inspirada no ethos realista, nunca pretendeu afirmar-se como atividade independente e autônoma; não perseguiu uma estetização pura, desligada das outras formas de ruptura do automatismo rotineiro da vida cotidiana. Longe de ver nela - no jogo e na festa - obstáculos para a sua realização, fontes de impureza para as suas obras, desenvolveu-se em conexão com elas, usando-as como material do seu próprio trabalho e servindo à complexificação e enriquecimento das mesmas (Echeverría 1996: 184).

Echeverría acrescenta que tal característica da arte barroca faz com que seja especialmente difícil abstrair as suas obras, como "pura arte”, do complexo conjunto que inclui a interação com as atividades lúdicas e cerimônias festivas. A seu ver, isso contribuiu para "desrealizar" a modernidade capitalista. E acrescenta que a presença histórica da arte barroca encontra-se, assim, intimamente conectada com a chamada cultura popular, "como cultivo dialético espontâneo da concreção histórica do código social e em especial como cultivo dialético da sociabilidade religiosa" (1996: 184).

Assim, a ideia de enquadramento do Jongo dentro do âmbito da cultura ou da religião perde completamente o sentido, uma vez que ele é regido por outras lógicas. Vejamos outro exemplo desta indissociação: a festa pelo 20 de Novembro, Dia da Consciência Negra, contou, em Colônia do Paiol, com a participação do Jongo de Bias Fortes. A apresentação do grupo visitante foi a última, feita já ao cair da tarde. Ao invés de subirem no altar, cantarem e dançarem, como fora feito pelos grupos de Maculelê e da Congada, os jongueiros saíram, posicionaram-se ao alto da rua principal do quilombo e deram início a uma procissão, que os levaria de volta à capela.

À medida que o Jongo avançava pela rua, os membros da comunidade iam incorporando-se ao grupo, que engrossava na proporção dos passos. Alguns assistiam de fora, outros ingressavam no cortejo, cantando e dançando alegremente. Eu mesma participei da caminhada. Posicionei- 
me na "linha invisível" que separava os jongueiros, que lideravam a procissão, e o restante dela. Estava, portanto, logo atrás do grupo de Bias Fortes - que se destacava pelo figurino branco e amarelo - e à frente dos quilombolas de Colônia do Paiol.

Sobre a mesma fronteira invisível também estava Paulo Marinho. Porém, mais uma vez, os dois olhares sobre a mesma situação guardavam grandes diferenças. Ele, iniciado no Jongo, dominava seus códigos - sabia que aquele limite não poderia ser ultrapassado.

Eu mantive distância do grupo de jongueiros por respeito, quase intuitivamente; já Paulo Marinho tinha outros motivos. No dia seguinte, numa conversa informal sobre as comemorações da véspera, a sua sobrinha, Maria José Franco, pergunta-lhe: “Tio, o senhor estava cantando tão bem o Jongo, por que não entrou na roda?”. Com sua maneira espontânea de reagir, o senhor Paulo Marinho arregala os olhos e responde: "Que é isso! Eu não podia! Não tinha o corpo fechado!” Ou seja: sem uma preparação prévia, a sua inserção no Jongo o deixaria desprotegido e exposto às dinâmicas internas, restritas aos iniciados, que ocorrem paralelamente àquilo que um olhar externo caracterizaria apenas como um belo e alegre folguedo.

\section{Considerações finais}

Vimos que a metáfora do barroco busca representar um mundo estetizado, teatralizado, afeito às aparências, sensorial e ambíguo. É o espaço do corpo, do riso, do excesso e da carnavalização - sendo, portanto, contrário ao modelo desencantado da modernidade.

A modernidade hegemônica pauta-se na nítida separação entre a vida cotidiana - tempo da rotina e da produção - e os momentos de ruptura. Os últimos, segundo Bolívar Echeverría, são tidos como improdutivos e adquirem um caráter de exceção:

\footnotetext{
Sem se confundirem entre si, mas estreitamente entrelaçadas uma à outra, as duas modalidades da existência humana que se desenvolvem nestes dois momentos do tempo cotidiano sempre dependeram, desde tempos arcaicos, da forma do tecido que as junta. Por esta razão, quando a modernidade se empenha em reduzir estas formas complexas a uma forma simples de intercalamento monótono e superficial de breves interrupções improdutivas no curso de um tempo dedicado quase por inteiro à produção de mercadorias e à reprodução da força de trabalho, encontra resistências insuperáveis (Echeverría 1996: 168).
}

Longe de ser desencantado, o mundo dos quilombos - como tantos outros - é invadido pelo estético. Ritualidade e mistificação, que transformam a realidade em beleza, formam a base da estetização da vida cotidiana e compõem o espaço-tempo das comunidades, espalhando-se através das mais variadas manifestações do sagrado. Mitos deixam-se narrar; forças sublimes aproximam-se do mundano através dos rituais; santos tornam-se amigos e até assombrações fazem-se pressentir em determinados pontos do território.

O sagrado e o simbólico estão no dia-a-dia, revelando-se com maior exuberância nos dias de festa. Portanto, as manifestações ali presentes revelam uma multiplicidade de sentidos, que se entrelaçam com a realidade e com as memórias da comunidade. No caso dos quilombos, que são cotidianamente atravessados pelas tensões do entorno, isto se vê refletido nas suas celebrações.

Foi discutido que a metáfora do barroco, no âmbito aqui proposto, promove uma prolife- 
ração de sentidos que subverte as mensagens originais. Desta maneira, a mestiçagem consiste numa subversão codificada, como a caracterizou Santos (2002). Portanto, pode ser uma forma de resistência: a abertura a novas formas de significação; a apropriação criativa subalterna dos modelos impostos pelos dominadores. Ao colocar em xeque as concepções de tempo, ordem e causalidade vigentes (Fleck 2002), ela desestabiliza o substrato cultural dominante.

Paradoxalmente, ao mesmo tempo em que a mestiçagem dissimula, ela também mantém e exibe o conflito. Vimos com Echeverría (1994) que, através dela, o "não" se revela como um caminho tão rebuscado de "sins" que destrói as possibilidades de afirmação plena. O autor observa que, já no século XVI, os indígenas americanos integrados na vida citadina dos seus vencedores refuncionalizaram o europeu mediante um comportamento barroco: reinventaram o cristianismo católico, ao transladá-lo a uma representação ou teatralidade absoluta (Echeverría 2007). Portanto, esta foi uma curiosa conspiração: uma conspiração praticada, não confabulada e não preparada. Tratou-se, antes, de "ceder a uma deusa a fim de criar outra” (Echeverría 2007: 15).

A apropriação criativa de elementos oriundos da cultura hegemônica gera curiosas metamorfoses. Os dois exemplos citados - a Folia de Reis e o Jongo - revelam a ambivalência e o mistério da contradição estrutural interna do ethos barroco, como assinalou Echeverría (1998). Através da ambivalência, torna-se impossível a imposição de um sentido único, preciso e claro, o que permite concessões no plano evidente para ocultar vitórias num plano superior - a opção pelo terceiro excluído. Desta forma, a mestiçagem é uma das manifestações de uma capacidade metaforicamente barroca de quebra de dicotomias, que desestabiliza as binaridades sobre as quais é pautado o modelo hegemônico. Sagrado versus profano, riso versus seriedade, aparência versus seriedade; tais oposições dicotômicas tendem a desfazer-se.

Estes e outros aspectos das relações entre sagrado e profano revelam modelos diferentes de relação com a esfera divina, íntimas e cotidianas, que distam do silêncio circunspecto de Roma. Esta religiosidade não só permite o corpo e o riso, mas torna estes dois elementos importantes para a louvação. Tal caráter alegre e performático revela a resistência contida no hibridismo religioso - uma vez que a mescla dali resultante, denominada genericamente de catolicismo popular, revela dinâmicas sociais profundamente enraizadas e teimosamente resistentes ao paradigma hegemônico de ascese e desencanto.

Como explica Maravall, "o barroco parte de uma consciência do mal e da dor e a expressa" (2009: 248). Portanto, o já mencionado salto para o terceiro excluído está longe de ser alienação. Trata-se da expressão risonha de uma realidade objetivamente dura; é, afinal, uma das formas de enfrentá-la.

\section{REFERÊNCIAS BIBLIOGRÁFICAS}

Almeida, Alfredo W. B. 2002a. "Os Quilombos e as Novas Etnias". Pp. 43-82 in Quilombos: Identidade étnica e territorialidade, edited by E. O’Dwyer. Rio de Janeiro: Ed. FGV. 2002b. "As populações remanescentes de quilombos. Direitos do passado ou garantia para o futuro?”. Pp. 244-255 in Seminário Internacional as Minorias e o Direito, edited by A. Rios. Brasília: CEJF. 2005. "O direito étnico à terra". Orçamento E̊ Política Socioambiental, 13: 1-12. 
2008. Terra de quilombo, terras indigenas, 'babaçuais livres', 'castanhais do povo', faixinais e fundos de pasto: terras tradicionalmente ocupadas. Retrieved March 1º 2013 (http://www. novacartografiasocial.com/index.php?option=com_phocadownload\&view=category\&id= 28Itemid=69).

Arruti, José M. 2006. Mocambo: Antropologia e História do processo de formação quilombola. Bauru: Edusc.

Ávila, Affonso. 1971. O lúdico e as projeçôes do mundo barroco. São Paulo: Perspectiva.

Bandeira, Maria de L. and Sodré, Triana V. 1993. "O Estado Novo, a reorganização espacial de Mato Grosso e a expropriação de terras de negros. O caso Mata Cavalo", Cadernos do Neru, 2: 83-103.

Bennassar, Bartolomé and Marin, Richard. 2000. História do Brasil. Lisboa: Teorema.

Bernal, Óscar C. 2004. "Nuevos enfoques sobre el barroco y la (Pos)Modernidad (a propósito de los estudios de Fernando R. de la Flor)”, Dicienda. Cuadernos de Filología Hispánica, 22: 27-51.

Billi, Leila. 2005. Mudança de forma como elemento constitutivo do barroco. Retrieved March 12, 2011 (http://www.dominiosdelinguagem.org.br/pdf/d5-5.pdf).

Cabanne, Pierre. 2001. Barroco e Classicismo. Lisboa: Edições 70.

Campos, Adrelino. 2005. Do quilombo à favela. A produção do espaço criminalizado no Rio de Janeiro. Rio de Janeiro: Bertrand Brasil.

Dias, Paulo. 2001. “A outra festa negra”. Pp. 859-888 in Festa: Cultura e sociabilidade na América Portuguesa, v. II, edited by I. Jancsó and I. Kantor. São Paulo: Edusp/Imprensa Oficial/ Hucitec/Fapesp.

Echeverría, Bolívar. 1994. "El ethos barroco". Pp. 13-36 in Modernidad, mestizaje cultural, ethos barroco, edited by B. Echeverría. México: ENAM/E1 Equilibrista.

1996. "El ethos barroco y la estetización de la vida cotidiana". Escritos enero-diciembre: 161-188.

1998. La modernidad de lo barroco. México: Ediciones Era.

2007. Meditaciones sobre el barroquismo. Retrieved March 15, 2011 (http://www.bolivare. unam.mx/ensayos/Guadalupanismo\%20y\%20barroco.pdf).

Fanon, Frantz. 1975. Pele negra, máscaras brancas. Porto: Paisagem.

Fleck, Eliane C. 2002. "O pensamento mestiço. Gruzinski, Serge”. Boletim da ANPHLAC 13: 04-06.

Leite, Ilka B. 2000. "Os quilombos no Brasil: questões conceituais e normativas". Revista Etnográfica 4 (2): 333-354.

2004. O legado do testamento: a comunidade de Casca em perícia. Porto Alegre/Florianópolis: Editora da UFRGS/NUER-UFSC.

2007. O quilombo trans-bistórico, jurídico-formal e pós-utópico. Retrieved March 19, 2009 (http://www.socialsciences.manchester.ac.uk/disciplines/social anthropology/postgraduate/clacs/ documents/IBoaventurav2.pdf).

Lisboa, Armando M. 2003. Ethos barroco. Retrieved March 10, 2011 (http://www.portalcse. ufsc.br/ gecon/textos/2003/armando05-03.pdf).

Maravall, José A. 2009. A cultura do barroco. São Paulo: Edusp.

Méndez, Sigmund. 2006. "Del barroco como El ocaso de La concepción alegórica Del mundo”, Andamios 2 (4): 147-180.

Nascimento, Abdias. 1980. O quilombismo. Petrópolis: Vozes.

O’Dwyer, Eliane C. 2002. "Introdução: os quilombos e a prática profissional dos antropólogos". Pp. 13-42 in Quilombos: identidade étnica e territorialidade, edited by E. C. O'Dwyer. Rio de Janeiro: FGV/ABA. 
Ratts, Alecsandro J. P. 2000. “(Re)conhecer quilombos no território brasileiro: estudos emobilizações”. Pp. 307-326 in Brasil afro-brasileiro, edited by M. N. S. Fonseca. Belo Horizonte: Autêntica.

Santos, Boaventura S. 1994. "E1 Norte, E1 Sur, la utopía y el ethos barroco”. Pp. 311-332 in Modernidad, mestizaje cultural, ethos barroco, edited by B. Echeverría. México: ENAM/E1 Equilibrista, 311-332. 2002. A crítica da razão indolente. Contra o desperdício da experiência. Porto: Afrontamento. 2006. A gramática do tempo. Por uma nova cultura política. Porto: Afrontamento.

Silva, Djalma A. 2005. O passeio dos quilombolas e a formação do quilombo urbano (tese de doutorado). São Paulo: Pontíficia Universidade Católica de São Paulo.

Sodré, Muniz. 2005. A verdade seduzida: por um conceito de cultura no Brasil. Rio de Janeiro: DP\&A.

Toro, Boris E. 2009. "El par simulación disimulación y el arte de saber vivir". Alpha 28: 169-180. Weber, Max. 1982. Ensaios de Sociologia. Rio de Janeiro: Guanabara Koogan.

Wölfflin, Heinrich. 1991. Renacimiento y barroco. Barcelona: Paidós.

\section{Baroque manifestations: "Jongo" ANd "Folia" in the QUilombola commu- NITY OF ColônIA do PAIOL}

This article uses the metaphor of the Baroque (Santos 2002) to reflect on two specific cultural expressions in the quilombola (black) community of Colonia do Paiol, located in Minas Gerais, Brazil. Based on this theoretical perspective and using semi-structured interviews and participant observation as research strategies, the celebrations of "Folia de Reis" and "Jongo" are analyzed in relation to their ambivalences and polysemies, pointing to their importance as means of resistance in a context of structural oppression.

Keywords: baroque, quilombolas, black community, “jongo", "folia de reis”, resistance 